\title{
Organizational Change Capacity, Environmental Uncertainty, and Organization Performance Studies on Traditional Retail Ownership of Chinese and non- Chinese in Malang
}

\author{
Lussia Mariesti Andriany ${ }^{1}$, Mintarti Rahayu ${ }^{1}$, Djumahir $^{1}$ \\ ${ }^{1}$ Graduate Programme of Faculty of Economic and Business, University of Brawijaya, Indonesia
}

\begin{abstract}
This study aims to show the effect of Organizational Change Capacity (OCC) and environment uncertain on traditional retail performance. In addition, this study also shows how cultural differences, reflected in ethnic differences in retail ownership of traditional Chinese and non-Chinese will affect organizational performance, and to differentiate the effect of OCC and environment uncertain on organization performance. This study uses a quantitative approach as the primary analysis method to explain the research results that supported by qualitative information of interview. The samples were 37 retails in Malang City. The respondents are the owner of retail. Data were collected directly by survey method using questionnaire instrument. Then the data is analyzed in two stages. The first stage is confirmatory factor analysis to determine the scores factor of each indicator. Furthermore, multiple regression analysis with dummy variables is used to test the research hypothesis. The findings of research is empirical evidence the effect of OCC on organizational performance, role of cultural differences on performance, and culture role to differentiate the effect of OCC on organizational performance. Uncertainty does not affect organizational performance and cultural differences do not make a difference in predicting the external environment in traditional retail.
\end{abstract}

Keywords: culture differences, environmental uncertainty, organizational change capacity, organization performance

\section{Introduction}

Today organization will face more severe challenges. Business environment is constantly changing with higher competition level (Lawler and Woley, 2006; Hutabarat and Huseini, 2006). It attracted the leader attention of any organization that wants to survive in those conditions. But in reality, many organizations do not able to survive for several reasons. First, practice design always pushes to achieve stability and mentioning the changes importance with small portions (Lawler and Woley, 2006; Andrews, 1971). Second, the organization resources inability to understand the importance of change (Clarke, 1994). Third, notion that the changes is expensive (Lawler and Woley, 2006).

In short term, the organization stability will impact on value and high organizational performance, but in long term, organization stability would make organization difficult to adjust to their environment (Judge and Blocker, 2008). Accordingly, Welch (2005) in Judge and Douglas (2009) states that an organizations capability to make changes is key to win the 21st century competition and a new strategy is very important for organization (Lawler and Woley, 2006). In addition, training materials conducted by WHO (2003) shows the change is beneficial to maintain survival of organization to face tahun age change.

The above description shows that capability to make changes is very important for the organization. How large the organizations capability to make changes is known from Organizational Change Capacity (OCC). Elenkov and Judge (2005) refer to OCC as one of organizations dynamic capability to adapt old capability to new threats and opportunities as well as an organizations capability to create new ones. In line with the idea, Judge and Douglas says that OCC is a combination of managerial and organizational capability of an organization to adapt more quickly and effectively than their competitors in constantly changing circumstances. OCC description above shows that OCC would relate to how organizations can use their abilities to compete in a constantly changing situation. Some researchers previously had tried to unravel the relationship of OCC with organizational performance to prove that $\mathrm{OCC}$ is one of tools organization to compete. These studies show different results. Siggelkow and Levinthal (2003) argued that the higher the change capability of an organization, the higher of organization performance. In line with these findings, Judge and Elenkov (2005) also showed a positive relationship between the OCC and the organizations environmental performance. Conversely, Pagell and Krause (2003) showed that higher flexibility does not correlate on organization performance in manufacturing companies. The contradictory research findings made the need for reexamination the influence of OCC on organizational performance. 
Besides looking OCC as organization internal factors to respond the external environment, organizations also need to look at external environment itself. Organizations external environment is seen as an unpredictable dynamic conditions change, and can create opportunities and challenges for organization (Child, 1997; Swamidass and Newel, 1987; Clarke, 1994). Therefore, success also depends on organizations capability to monitor their external environment (Boyd and Fulk, 1996). Organizational difficult to forecast external environment changes, especially related to the market demand and the competition level (Suardhika, 2011), is a source of organization uncertainty (Miliken, 1987).

Several previous studies indicate the organizational external environmental uncertainty level will affect Organization Performance. Wiklund (1999) states the external environmental uncertainty level influence organizations organizational performance regardless of chosen strategy. This finding was supported by Nurhajati (2004) which states that external environment related to customer positively affect organizational performance. These results are contrast to Suardhika (2011) which states that an increase in environment uncertain and competition intensity faced by organization is able to inhibit or degrade their performance. In contrast to these three studies, other studies found no association between external environment on organizational performance (Pagell and Krause, 2003) and found no direct relationship between the two variables (Pelham, 1999; Rivard et al., 2005; Parnell et al., 2000). Contradictory results of these studies provides an opportunity to further explore the relationship between the environmental uncertainty, manifested in competition level and changes in market demand on organization performance.

The description above shows two research gap. First, it has not been showed clearly how the relationship between OCC with organization performance in various industries type. Second, there are different views the role of environmental uncertainty in relation with organization performance. Previous research gaps will require disclosure the relationship between OCC and environmental uncertainty on organizational performance in a particular cultural context, in accordance with suggestions for future research of Judge and Douglas (2009). A study on different cultures serve to broaden understanding of OCC because in different cultures, organization capability to change and adapting to business environment will be different (and Wolliams Trompenaars, 2003).

Some previous research has shown about how culture affects organizational perspective on changes, organization external environmental conditions, and organizational performance. Judge and Elenkov (2005) tried to examine how the relationship OCC and performance in Bulgaria organizations. The results showed a strong positive correlation between OCC and business environment performance. Furthermore, Kirsch et al. (2012) stated that culture will have an impact on organization changes. The results stated that difference in performance improvement, turbulence, communication, management of change, employee engagement and emotional expression are influenced by cultural dimensions. Harzig and Hofstede (1996) also showed the effect of culture on change resistance level. Based on the description, researchers are interested to uncover effect of cultural, which is reflected in ethnic ownership of an organization namely Chinese and non-Chinese, on organizational performance and relationship between OCC and environmental uncertainty on organization performance.

Chinese ethnicity selection as basis of cultural differences is based on several reasons. First, the dominance of Chinese ethnic in trade sector, especially in Indonesia is very visible. Fujitsu Research Studies in Tokyo Japan stated that approximately $73 \%$ of businesses in Indonesia is controlled by Chinese ethnic (Munarwan, 2011). In addition, business operated by Chinese generally appears as a dynamic business (Rahayu, 2005).

Based on description above, the purpose of this study is to show the effect of OCC and environment uncertain on organization performance. In addition, this study also aims to uncover the role of cultural differences in distinguishing organizational performance, and the effect of OCC and environment uncertain on organization performance. The explanation is expected to expand knowledge the relationship of OCC, environmental uncertainty, and organization performance. In addition, description the relationships in different ethnic are expected to expand the organization concept operated by Chinese and non-Chinese ethnic. This study is also expected to provide practical benefits for businesses so they can understand the change is unavoidable in running the business. Retailer can also find out how retailer with different cultures manage and utilize its business to keep their businesses.

\subsection{Organizational Change Capacity $(\mathrm{OCC})$}

\section{Theoretical and Literature Review}

Organizational Change Capacity (OCC) or organization capacity to change is a combination of managerial and organizational capability of an organization to adapt more quickly and effectively than their competitors in changing circumstances (Hatum and Pettigrew, 2009; Judge and Douglas, 2009; Buono and Kerber, 2009). In another study, the OCC is referred to as dynamic organizational capability to adapt old capability to new threats and opportunities as well as an organizations capability to create a new (and Elenkov Judge, 2005). OCC concept relates to other concepts, such as organizational flexibility (Palaniswamy and Sushil, 
2003), which is the capacity to respond to environmental changes. In addition, the OCC also related to an organizations willingness to accept change, where the idea began to grow in line with the importance of change for an organization (Butler, 2003). OCC concept is also known as a unique concept for a few reasons (and Elenkov Judge, 2005). First, the OCC is a concept that saw the readiness of all aspects and not just individuals within organization to change (Cunningham et al., 2002). Second, the concept is not just looking at OCC as intangible organizational capabilities, such as individual capability, but also looks at tangible organization capability, such as organizational infrastructure to promote or inhibit the change (Tsoukas and Chia, 2002).

Previous description shows that OCC would relate to how organizations can use the capability owned, both managerial capability as intangible capabilities of organization, and intangible organizational capabilities, to apply those capabilities to face threats and opportunities posed by competition condition that constantly change (and Elenkov Judge, 2005; Judge and Douglas, 2009; Hatum and Pettigrew, 2009).

\subsection{Environmental Uncertainty}

Environmental uncertainty is organization inability to predict accurately their external environment (Miliken, 1987) which is seen as an dynamic conditions with unpredictable change, and can create opportunities and challenges for organization (Child, 1997; Swamidass and Newel, 1987; Clark et al., 1994), so the organization success depends on their capability to monitor their external environment (Boyd and Fulk, 1996). Organizations external environment consists of competition level conditions and consumer tastes changes (Rivard et al. 2005) that would make organizations continues to seek ways to adapt in order can survive and winning competition (Suardhika, 2011).

\subsection{Organization performance}

Each organization will always strive to achieve the decided goals. Goal is the end result being pursued through the existence of company and its operations, such as sustainability, profitability, efficiency, satisfaction, and employee development, quality of products or services to consumers, market leadership, and so forth (Glueck and Jauch, 1988). Generally, the concept of organizational performance is based on idea that company is a collection of productive assets, including human resources, physical resources and capital, to achieve a common goal (Carton and Hofer, 2006). Business performance, beside become a reflection of organization success or failure, can also describe the results achieved by organization of series of implementation of work function or activity in a given period (Wheelen and Hunger, 2011). In a study of small and medium enterprises, the performance appraisal is done by using the financial and non-financial approach to measure the extent a business achieve its goals (Chong, 2008). The statement supports the suggestions for future studies of Parnell et al. (2000) which states that a comprehensive performance assessment is important to do to get comprehensive information about organizational performance.

\subsection{Organizational Change Capacity and Organization Performance \\ III. Research Hypothesis and Research Model}

Several previous studies show different results regarding the relationship between OCC and organization performance. Siggelkow and Levinthal (2003) argued that if organizations are increasingly able to change, then their relative performance will be higher. Meanwhile, Judge and Douglas (2009) showed there is a relationship between organization capacity to change and capability to generate competitive advantage. Judge and Elenkov (2005) also showed a positive relationship between OCC and organizations environmental performance. Adversely, Pagell and Krause (2003) showed the increase in flexibility is not related to the organization performance in manufacturing companies. Description of research results made researcher interested in studying again the effect of OCC on organization performance using the following hypothesis:

\section{H1: Organizational Change Capacity (OCC) affect on organization performance.}

\subsection{Environmental Uncertainty and Organization Performance}

This study assumed the environmental uncertainty affect organizational performance. Environmental uncertainty is seen as an organizational inability to predict accurately their external environment (Miliken, 1987). Previous researchers showed different results for the relationship of environment uncertainty and organization performance. Wiklund (1999) states that organizations external environment affect their performance regardless of chosen strategy by organization. Nurhajati (2004) states that external environment that related to buyers positively affect organizational performance. This is in contrast to results Suardhika (2011) which states that environmental uncertainty and the intensity of competition faced by organization is able to inhibit or degrade their performance. In contrast to the three studies, other studies have found no link between the external environment and organizational performance (Pagell and Krause, 2003) and found no direct relationship between the two variables (Pelham, 1999; Rivard et al., 2005; Parnell et al., 2000). Description of studies results 
allowed the researchers keen to re-examine the effect of environmental uncertainty external to organizational performance using the following hypothesis:

H2: External environmental uncertainty affects the organization performance.

\subsection{The role of culture in relationship between the $\mathrm{OCC}$, environmental uncertainty, and organization performance}

Research Kirsch et al. (2012) stated that difference in performance improvement, turbulence, communication, change management, employee engagement and emotional expression, is affected by cultural dimensions. Cultural differences will impact on how organizations create structures, how employees are motivated, and what approach used to change and becoming the most successful (Kirsch et al., 2012). Accordingly, Walumbwa et al. (2007) says that cultural differences will affect on organizational change and organizational characteristics, such as compensation system, performance appraisal, teamwork and team collaboration, organizational structure, and leadership style. Research results by Harzig and Hofstede (1996) shows the effect of culture on level of resistance to change. Based on these explanations, the researchers will use culture as a factor that distinguishes organizational performance, and differentiate the effect of OCC and environment uncertain on organization performance. Hypotheses constructed based on above description are:

H : Culture will become variables that play a role to differentiate the organization performance .

H3a : Culture will become variable that plays a role to differentiate the effect of Organizational Change Capacity on organization performance.

H3b : Culture will become variable that plays a role to differentiate the effect of environment uncertain on organization performance.

From the explanation above, it can be drawn a research model in Figure below.

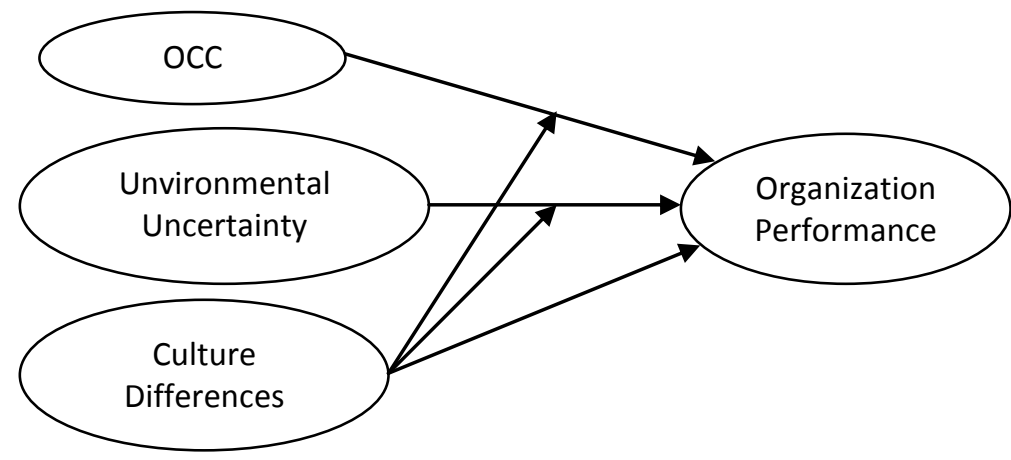

Figure 1

Research Model

\subsection{Research Context}

\section{Methodology}

The context of this study is to explain the relationship between variables at traditional retail in Malang City, East Java, Indonesia, where based on several reasons. First, the retail itself is a business that growing rapidly in provinces and cities in Indonesia, one of them in Malang City, East Java. This is evidenced in Surabaya Post online article explanation in 2011 that retail growth in East Java reached 7\% and dominated by national network establishment of modern retail. Malang, a city with significant economic growth in East Java, which reached $6.7 \%$, is a city dominated by the growth of modern retail development (PPOTODA, 2012). Department of Industry Malang recorded 91 modern retail minimarket has been established, with a composition of 54 Indomaret and 37 Alfamart. Total modern retail minimarket far beyond the ideal limit, the number of 18 to 20 modern retails (PPOTODA, 2012). Unfortunately, the growth in a number does not occur in traditional retail that decreased by $8 \%$ per year (Kurniawan, 2012). Second, an increasing the number of modern retail impact on traditional retail performance as evidenced by a decline in traditional retail turnover by $30 \%$ (Kurniawan, 2012). It is also mentioned by Saddewisasi et al. (2011) and Suman (2011), that an increasing number of modern retail cause a decrease in sales turnover, turnover and gross profit from traditional retail. If the condition is continue, it will kill traditional retail today. Third, there is an imbalance competition between traditional retail and modern retail, so the bargaining position of traditional retail declines (Suman, 2011). In addition, Kasali (2007) also noted that changes in incomes structure, consumer time constraints, availability of electronic payment instruments, and refrigeration, are also the things that making role of traditional retail business fades. 


\subsection{Population and Sample}

This study population is an infinite population. Therefore, it decided some conditions to obtain the population. First, the traditional retail distances up to 500 meters away from the study of modern retail, taking into account the Regional Regulation No. 8 of 2010 which states that establishment of a modern shop should only be done at a distance of 500 meters between stores modern and traditional shops. In fact, the establishment of modern stores do not consider the regulations, so there is a traditional store located at a distance less than 500 meters from the modern shops. Second, the traditional retail around modern retail is owned by Chinese and nonChinese ethnic to know the difference of performance, OCC relationships and environmental uncertainty performance between the traditional retail ownership of Chinese and non-Chinese ethnic in Malang City. Based on these criteria 37 traditional retail is determined. It is a census population. This amount meets the minimum sample requirements proposed by Hair et al. (2010) which states that minimum amount is five times the indicator sample study, the number of 35 retails. The respondents are owners of traditional retail, because they most familiar and responsible to maintain the organization viability.

\subsection{Research Variables and Measurement}

\subsubsection{The Independent Variables}

- Organizational Change Capacity

The operational definition of variables OCC is capability to apply the traditional retail managerial and organizational capability possessed, so retailers can adapt to the changing business environment and survive in those conditions. Managerial capability seen through the capability and willingness of retail owners to change in accordance with changes in business environment, while the organizational capabilities can be seen through venture capital and suppliers availability (Judge and Douglas, 2009; Buono and Kerber, 2009).

- Environmental Uncertainty

Operational definition of environmental uncertainty is the retailer's inability to predict the changes from organizations external environment. Variable environmental uncertainty has two indicators refer to Rivard et al. (2005) and Khandwalla (1977) that has been adapted to the study context, the competition level from modern retail and consumer tastes change.

\subsubsection{The Dependent Variable}

- Organization Performance

Operational definition of organizational performance is the end result of activities undertaken based on resources and has two indicators reflecting the financial approach and non-financial as an approach for performance assessment of small and medium enterprises (Chong, 2008). Profitability is seen through profit and capital, and market is seen through a number of sales and consumer of traditional retail (Sanchez and Marin, 2005).

Independent and dependent variables measured using a 5-point Likert scale, where point 1 indicates strongly disagree and point 5 indicates strongly agree.

\subsubsection{Dummy Variable}

\section{- Cultural Differences}

Operational definitions of cultural differences variables are difference of Chinese and non-Chinese ethnic differences proxied with traditional retail owners that make a difference in basic values of traditional retail business that will be different, both in terms of performance and relationship of OCC and environmental uncertainty on organizational performance. Traditional retails of Chinese ethnic were coded with numbers 1 and 0 for traditional retail non-Chinese ethnic.

\subsection{Methods of Data Collection and Analysis}

Data was collected through direct survey method with questionnaire instrument or a list of statements given to respondents. Furthermore, the researchers also conducted interviews with some of traditional retail owner, both Chinese and non-Chinese ethnic. Interviews were conducted to obtain information from owner related to their response to changes of business environment conditions, as well as enriching the quantitative data obtained from the questionnaire. Research instruments were then tested for validity and reliability. Validity test performed to test the accuracy of research instrument size (Sekaran, 2006). It is valid if able to measure accurately what is to be measured. Validity test is performed by bivariate Pearson product moment correlation. A research instrument is valid if the value of correlation coefficient is significant, both at the level of $1 \%$ and $5 \%$ (Ghozali, 2011). Reliability test is used to measure the consistency of indicator variables. Reliability tests conducted using Cronbach Alpha $(\alpha)$ and is said to be reliable if it consistently led to the same result for each 
time measurement (Ferdinand, 2006) or have a Cronbach Alpha $(\alpha)$ above 0.60 (Nunnally, 1978 in Chew et al., 2008). The result of validity and reliability test is all items in instrument are valid and reliable.

This research used descriptive analysis and inferential analysis. Descriptive analysis method is used to give an idea of respondents profile and variables description, inferential statistics to test hypotheses of study, and qualitative data analysis to generate the required supplementary information to enrich the results of quantitative analysis. Inferential statistical methods used in study are a confirmatory factor analysis function to see the scores factor of each indicator variable and multiple regression analysis with dummy variables to examine the relationship between the study variables and prove the research hypothesis.

\subsection{Respondents Characteristics}

\section{Research Result and Discussion}

The data analyzed in this study are based on research instrument that is distributed directly to all respondents of 37 traditional retails. All instruments distributed can be used in analysis. Therefore, the instrument used level is 37 units or $100 \%$. The initial phase of data analysis is descriptive statistical analysis. One results of statistical analysis is the descriptive characteristics of respondents, as shown in Table 1 below.

Table 1

Respondent Characteristics

\begin{tabular}{|c|l|c|c|}
\hline No & \multicolumn{1}{|c|}{ Characteristic } & Number & Percent (\%) \\
\hline $\mathbf{1}$ & Sex & & \\
\hline & Males & 10 & $27.03 \%$ \\
\hline & Females & 27 & $72.97 \%$ \\
\hline $\mathbf{2}$ & Development Year (2002 $\rightarrow$ early modern retail development) & & \\
\hline & Until 2002 & 29 & $78.38 \%$ \\
\hline & After 2002 & 8 & $21.62 \%$ \\
\hline $\mathbf{3}$ & Distance from Retail Modern & & \\
\hline & Until 100 meter & 15 & $40.54 \%$ \\
\hline & $>100-200$ meter & 6 & $16.22 \%$ \\
\hline & $>$ 200 - 300 meter & 9 & $24.32 \%$ \\
\hline & $>300-400$ meter & 3 & $10.81 \%$ \\
\hline & $>$ 400 - 500 meter & & $8.11 \%$ \\
\hline $\mathbf{4}$ & Ownership & 16 & $43.24 \%$ \\
\hline & Chinese & 21 & $56.76 \%$ \\
\hline & Non-Chinese & & \\
\hline
\end{tabular}

Source: data processed (2013)

\subsection{Research Variable Profiles}

The study of research profile is conducted to explore the variables studied based on scores factor, mean, and results of interviews in this study.

\subsubsection{Profile of Organizational Change Capacity}

The study results in Table 2 show that organization owner capability to change, organization owner willingness to change and resources organization has been confirmed as managerial and organizational capabilities that support organization to change and adapting to environmental conditions. This is evidenced by all the indicators have a significant factor score (Sig. <0.05). The capability of traditional retail is strength for the business in order able to compete with modern retail. The results of this study reinforce Judge and Douglas (2009) and Kerber and Buono (2009) that capability is a source to compete in a constantly changing environment. Other information that can be extracted from Table 2 above is organization owner capability to change has the highest score $(0.888)$, followed by organization owner willingness to change $(0.861)$, and then owned resources $(0.734)$. These results meant that organization owner capability to change is the most important for an organization in supporting OCC, and make them survive in competition. However, respondent is highest in resources indicators with a mean of 3.72, while the organization owner capability to change has second rank with average of 3.57 . 
Table 2

Variable Profile: Organizational Change Capacity

\begin{tabular}{|l|c|c|c|}
\hline \multirow{2}{*}{ Indicators } & \multicolumn{2}{|c|}{ Score Factor } & \multirow{2}{*}{ Mean } \\
\cline { 2 - 3 } & Coefficient & sig. & \\
\hline The owner organization capability to change & $\mathbf{0 . 8 8 8}$ & 0.000 & 3.57 \\
\hline $\begin{array}{l}\text { The owner organization willingness to } \\
\text { change }\end{array}$ & 0.861 & 0.000 & 3.42 \\
\hline Resources owned & 0.734 & 0.000 & $\mathbf{3 . 7 2}$ \\
\hline
\end{tabular}

Source: data processed (2013)

This condition indicates that traditional retail owner thought that most important thing to establish their capability to change is organization resource, such as the availability of suppliers and working capital.

Thus, the traditional retail owners do not make their own capability to change as a priority in shaping the OCC. This is consistent with the fact that traditional retailers rely on salesman as their supplier. Therefore, the owner can not quickly replace old products with new products when salesmen come late or did not come to their store. In addition, the majority of products sold by owner of a traditional retail supplied by salesmen who came to them. Therefore, selling price of product will depend on purchase price of product at the salesman. It is not seen as an attempt to adjust the prices of products sold for the latest products by traditional retail owner. The owner did not take the traditional retail items in bulk. It increases the risk of causing business owners do not get a discount from the salesman. It certainly makes the owners are increasingly dependent on base price given by the salesman with no discounts for quantity purchases.

\subsubsection{Profile of Environmental Uncertainty}

The study results in Table 3 show that competition level from modern retail and consumer tastes change are indicator that not confirmed as indicator to make traditional retailers not able to see their external environment condition. It is known from the significant value of factor score that more than 0.05 . This result means do not support the environmental uncertainty concept from Rivard et al. (2005) and Khadwalla (1977).

Table 3

Variable Profile: Environmental Uncertainty

\begin{tabular}{|l|c|c|c|}
\hline \multirow{2}{*}{ Indicators } & \multicolumn{2}{|c|}{ Score Factor } & \multirow{2}{*}{ Mean } \\
\cline { 2 - 3 } & Coefficient & sig. & \\
\hline The competition level with modern retail & 0.765 & 0.316 & $\mathbf{3 . 6 8}$ \\
\hline Consumer tastes change & 0.765 & 0.316 & 3.48 \\
\hline
\end{tabular}

Source: data processed (2013)

Conditions in Table 3 shows that competition level from modern retail as well as changes in consumer tastes do not actually make the organizations external environment becomes unpredictable. These results are due to the capability of traditional retailers to adapt to the environmental conditions encountered. In addition, traditional retail also use promotions from modern retail to customize the type of products sold and know the latest price of product. This utilization makes traditional retail able to predict consumer tastes. Therefore, products obsolescence sold by traditional retail can also be avoided. Based on this, the traditional retail actually has been able to predict their external environment despite retail owner considers the competition level from modern retail and consumer tastes change as a source of environment uncertain that will make the traditional retail difficult to survive in a changing environment.

\subsubsection{Profile of Organization Performance}

The study results in Table 4 show that profitability and financial market activity are confirmed as nonfinancial and financial activities to create organizational performance. This is evidenced from all the scores factors of performance indicators with significance value lower than 0.05 . These findings reinforce the measurement model of Chong (2008) and Sanchez and Marin (2005). 
Table 4

Variable Profile: Organization Performance

\begin{tabular}{|l|c|c|c|}
\hline \multirow{2}{*}{ Indicators } & \multicolumn{2}{|c|}{ Score Factor } & \multirow{2}{*}{ Mean } \\
\cline { 2 - 4 } & Coefficients & sig & \\
\hline Profitability & 0.924 & 0.000 & $\mathbf{3 . 6 3}$ \\
\hline Market & 0.924 & 0.000 & 3.59 \\
\hline
\end{tabular}

Source: data processed (2013)

Other information that can be extracted in above table is the scores factor of two indicators in organizational performance is same, amounting to 0.924 . Conceptually, it shows the profitability and market is an important measure in achieving the organization performance because the profits increased and capital will make the traditional retail market increase, whereas an increase in sales and consumers will increase the profits and provide opportunities for retail owners to raise the working capital. However, the traditional view that retail owners achieve high profitability is the strongest measure of performance. This is evident from the mean is higher market indicators score. This means that traditional retailer owners focus their efforts to improve profitability and increase business capital rather than expand the market by trying to increase the number of customers and the number of sales by increasing the number and variation of products sold.

These findings indicate that both indicators that having role in shaping the organization performance has not been fully achieved by traditional retail. This finding is consistent with the fact that traditional retail owners tend to keep their customers because their reluctance to seize other retail customers. It happened due to traditional retail owner considers that seizing other retail customers is unfair competition.

\subsection{Hypothesis Testing}

Hypothesis testing is done by looking at significance value of each relationship between independent and dependent variables in the research model. Table 5 shows the test results for each hypothesis by looking at t-test to see significance the relationship of each variable included in model as well as to test the research hypothesis.

Tabel 5

Research Hypothesis Test Result

\begin{tabular}{|c|l|c|c|c|}
\hline \multirow{2}{*}{ Notation } & \multicolumn{1}{|c|}{ Variable Relationship } & \multicolumn{2}{c|}{ T test } & \multirow{2}{*}{ Result } \\
\cline { 3 - 5 } & & t-count & Sig. & \\
\hline H1 & OCC $(\mathrm{X} 1) \rightarrow$ Performance (Y) & 7.100 & 0.000 & Accepted \\
\hline H2 & Environmental Uncertainty (X2) $\rightarrow$ Performance (Y) & 1.723 & 0.094 & Rejected \\
\hline H3 & Cultural Differences (D) $\rightarrow$ Performance (Y) & -2.130 & 0.041 & Accepted \\
\hline H3a & Cultural Differences (D) $\rightarrow$ OCC (X1) - Performance (Y) & 3.189 & 0.003 & Accepted \\
\hline H3b & $\begin{array}{l}\text { Cultural Differences (D) } \rightarrow \text { Environmental Uncertainty } \\
\text { (X2) - Performance (Y) }\end{array}$ & -0.5 & 0.620 & \multirow{2}{*}{ Rejected } \\
\hline
\end{tabular}

Source: data processed (2013)

\subsubsection{T-test Results}

Table 5 shows significance the results obtained for each variable relationships or hypotheses. It can be described as follows:

\section{- H1 : Organizational Change Capacity (OCC) affect on organization performance}

Table 5 shows that value and significance for the relationship of OCC on organizational performance is 0.000 or less than 0.05 . It means OCC affect organizational performance. T-count results are 7.100 and are positive. This means an increase in managerial and organizational capability of an organization will be accompanied by an increase in organization performance. Thus, the first hypothesis (H1) of this study is accepted. The study findings illustrate that traditional retail in Malang City has managerial and organizational capability to improve their performance. Through the capabilities, traditional retail can adapt to external environment change and remain competitive in this condition. These results reinforce the findings of Siggelkow and Levinthal (2003), Judge and Douglas (2009), Judge and Elenkov (2005) which states that Organizational Change Capacity affect organizational performance. Meanwhile, the findings of this study do not support Pagell and Krause (2003) who suggested the increased flexibility does not have a relationship with organization performance in manufacturing companies. 
Based on above presentation, it can be asserted that in order to improve the traditional retail performance environment in changing conditions, managerial and organizational capabilities are needed in order traditional retailers can adjust and maintain survival of organization. Thus, these findings confirm the uniqueness presented by Cunningham et al. (2002) and Tsoukas and Chia (2002) that concept of OCC look at all aspects of organization, the individual aspects and resources that will encourage or discourage a change in organization.

\section{- H2 : External environmental uncertainty affects the organization performance}

Information from Table 5, with respect to environmental uncertainty and organizational performance, is significant at 0.094 and $t$ values of 1.723 . These results suggest that second hypothesis $(\mathrm{H} 2)$ is not accepted. These results meant that environmental uncertainty, derived from the competition level and changing consumer tastes, is not a factor that makes the traditional retail performance decline. This finding is interesting because the traditional retail in Malang able to produce a good performance in a changing environment.

These findings support the research hypothesis of Pagell and Krause (2003) who stated that external environment does not relate to the performance of manufacturing firms in United States. Moreover, the results also support Pelham (1999), Rivard et al. (2005), and Parnell et al. (2000) that there is no direct relationship between the two variables. In contrast, this study differ with the results of research Suardhika (2011) that the environmental uncertainty is part of business environment dynamics that will degrade SMEs performance in Bali and Nurhajati (2004) which showed that external environment related to buyers will affect the SMEs performance in East Java.

The hypothesis test results show the traditional retail in Malang has been able to overcome the external environmental uncertainty by utilizing their managerial and organizational capability. The usage is consistent with the fact that traditional retail owners always try to get information about new products and the latest price of products sold. The information is obtained in several ways, namely through the electronic media, salesmen or business suppliers who come to shop, and the usage of promo done by modern retail. In some ways, the traditional retailers are able to know the new products launched in market and the impact on their performance. Hypothesis testing results explanation inline with Rivard et al. (2005) which states that an increase in environmental uncertainty will make small businesses always look for ways and taking advantage of every opportunity continuously. It will impact on their business performance.

- H3 : Culture will become variables that play a role to differentiate the organization performance

Table 5 shows information that t-count and significance the relations of cultural differences on organizational performance are at -2.130 and 0.041 . The significance is lower than 0.05 . It means that cultural differences variables are variables that can distinguish organizational performance. The findings from this hypothesis testing supports Kirsch et al. (2012) and Walumbwa et al. (2007) which states that different cultures will affect the organization performance. Value of t-count indicates that traditional retail performance of non-Chinese ethnic as an excluded group $(\mathrm{D}=0)$ is better than the Chinese ethnic retail as included group $(\mathrm{D}=1)$, where business founded by Chinese ethnic were seen as a dynamic (Rahayu, 2005). Negative results of this hypothesis test is inline with the different ways to survive for traditional retail-owned of Chinese ethnic and non-Chinese. This impact on performance perception of business owner. To survive the competition, traditional retail ownership of non-Chinese ethnic make diversification by opening other business, such as opening a pulse counter, restaurant, and LPG dealer. Diversification efforts to make venture capital, profits, number of customers, and increase the number of products sold. While the Chinese ethnic owners do not diversify the business, but retain their early business while maintaining customer loyalty and attention to consumer tastes. Thus, differences way in traditional retail to maintain business make owners perception is different to organization performance.

- H3a : Culture will become variable that plays a role to differentiate the effect of Organizational Change Capacity on organization performance.

Table 5 shows that $t$ count and significance for the relationship of cultural differences and OCC are 3.189 and 0.003 . These results meant that cultural differences that reflected in traditional retail ownership differences of is a variable to differentiate OCC of an organization. These results corroborate the results of studies of Kirsch et al. (2012), Walumbwa et al. (2007), as well as Harzig and Hofstede (1996) which states that cultural differences will make a difference in perspectives and approaches to organizational change.

OCC with Chinese traditional retail ownership as included group $(\mathrm{D}=1)$ is better than non-Chinese ethnic as excluded group $(D=0)$. This result is consistent with the fact that Chinese traditional retailers are able to provide a cheaper price than non-Chinese retailer. Retail owners realize that their consumers are very 
sensitive to price, so the owners always try to adjust the prices of products sold with latest market price. The Chinese traditional retailers have no inventory of large quantities products because most of their products are perishable and the prices change rapidly. Supply arrangements could be made because the owner has a good relationship with a number of suppliers namely salesmen and wholesalers who was instrumental in providing the requested product owner at any time (Halim, 2007).

Retail owners are also trying to establish good relations with customers in several ways. First, the owner communication with consumers is not limited to products that consumers want to buy, but the owner also tried to gather information about consumer tastes while offering products sold outside of products that consumers want. Second, owners try to help consumers by providing information on products when consumers have many choices of one product to be purchased. The explanation is inline with Halim (2011) which stating that Chinese people are friendly with their customers. In line with the statement, Munarwan (2011) showed that Chinese are able to capture buyer confidence with communicating to their customers.

When linked with the organization performance, managerial and organizational capability, traditional retailer ownership of Chinese ethnic apparently have an impact on a better performance than the traditional retail ownership of non-Chinese ethnic. This is evidenced by the value of t-count for cultural differences dummy on OCC is higher than cultural difference dummy on performance. Thus, the cultural differences is a variable that distinguishes OCC effect on organizational performance.

\section{- H3b : Culture will become variable that plays a role to differentiate the effect of environment} uncertain on organization performance.

Information from Table 5 for the relationship between cultural differences and environmental uncertainty has $\mathrm{t}$-count of -0.5 and significance of 0.62 . These results indicate that cultural differences is not a variable to differentiate traditional the retail perspective to their external environment. These results reject Harzig and Hofstede (1996) which stating that cultural differences have an impact on their level of prevention against alteration.

The results are consistent with the fact that retail traditional ownership of Chinese and non-Chinese are able to predict their external environment. The study findings is inline with the explanation of environmental uncertainty which shows that even though the traditional retail owners generally considered environment uncertain as a thing that can not be predicted, but they make an effort to survive. Managerial and organizational capabilities have made them capable to face external environment and no impact on performance. In addition, research duration is less than 10 years from the rise of modern retail establishments that have an impact on relations with the cultural differences, environmental uncertainty and performance. In past 10 years, the traditional retail ownership of both ethnic groups have been looking for a way to survive in competition by utilizing their managerial and organizational capability. The explanation is inline with statement of Rivard et al. (2005) that in an uncertain environment, small businesses will find a way to survive that impacting on their business performance. Therefore, cultural differences did not distinguish the effect of external environmental uncertainty on organizational performance.

\section{Conclusion}

Based on research findings that has been described, the result results has prove empirically the findings of Siggelkow and Levinthal (2003), Judge and Douglas (2009) and Judge and Elenkov (2005) about the relationship between the OCC and the organization performance. In addition, dummy variable of cultural differences is used in this study to differentiate traditional retail ownership. Study findings the effect of cultural differences on organizational performance, the relationship of OCC and environmental uncertainty on organization performance demonstrate the empirical future research suggestions proposed by Trompenaars and Wolliams (2003). These study findings showed that cultural differences would distinguish the relationship of organizational performance and OCC on organization performance. The findings of this study support the concept of Kirsch et al. (2012), Walumbwa et al. (2007), and Harzig and Hofstede (1996) which showed that in different cultures, organizational responses to change will be different, therefore the organizational performance would be different.

The results of this study provide practical implications with respect to the use of managerial and organizational capability to maintain and improve business performance and address the Environmental uncertainty caused by competition level with modern retail and changing consumer tastes. To take advantage of these capabilities, the retail owner should focus on their capability and willingness. It proved important to encourage organizations to change and to adapt with business environment. With the capability and willingness to change, retail owners will be able to utilize capital resources and suppliers that had already possess.

Another practical implication of this study findings is the ethnic differences in traditional retail ownership will make the owner will use differ way to maintain organizations and impacting on OCC difference. Traditional retail ownership of non-Chinese ethnic can learn how retail owners communicate with the Chinese people to 
win consumers trust and leverage resources to sustain their business. By doing this, the Chinese traditional retailers are able to perform better than non-Chinese traditional retailer despite the non-Chinese retail performance is proved better.

Limitation of this study is using perception method in measuring the perception of organizational performance. Therefore, future researchers can use more than one method of measuring performance with the goal to minimize measurement bias due to different perceptions. In addition, future research should also consider the consumers as respondents, because the study results stated that communication is an important factor to retain customers besides adjusting the products sold with consumer tastes. Consideration is needed to conduct research in a larger scale or with different ethnic comparisons in order the results of this study can be generalized.

\section{References}

[1] E.E. Lawler and C.G. Woley, Built To Change: How To Achieve Sustained Organizational Effectiveness (USA: John Wiley \& Sons, Inc., 2006).

[2] J. Hutabarat dan M. Huseini, Pengantar Manajemen Strategik Kontemporer: Strategik di Tengah Operasional (Jakarta, Indonesia: Elex Media Komputindo, 2006).

[3] K.R. Andrews, The Concept of Corporate Strategy (Illinois, USA: Dow Jones Irwin, Homewood, 1971).

[4] L. Clarke, The Essence of Change (UK: Prentice Hall International, Ltd, 1994).

[5] W.Q. Judge and C.P. Blocker, Organizational Capacity for Change and Strategic Ambidexterity: Flying The Plane While Rewiring It, European Journal of Marketing, 42, 9/10, 2008, 951-926.

[6] W.Q. Judge and T. Douglas, Organizational Change Capacity: The Systematic Development of a Scale. Journal of Organizational Change Management. 22, 6, 2009, 635 - 649.

[7] World Health Organization, Manajemen Perubahan (SEA-NURS-429, IN O OSD 001/1.2, 2003).

[8] W.Q. Jugde and D. Elenkov, Organizational Capacity for Change and Environmental Performance: An Empirical Assesement of Bulgarian Firms, Journal of Business Research, 2005, 893 - 901.

[9] N. Siggelkow and D.A. Levinthal, Temporarily Divide to Conquer: Centralized, Decentralized, and Reintegrated Organizational Approaches to Exploration and Adaptation, Organizational Science, 14, 6, 2003, 650-669.

[10] M. Pagell and D.R. Krause, Re-exploring the Relationship Between Flexibility and the External Environment, Journal of Operations Management, 2003, 1 - 44.

[11] J. Child, Strategic Choice in the Analysis of Action, Structure, Organization, and Environment: Retrospect and Prospect, Organization Studies, 18, 1997.

[12] P.M. Swamidass and W. Newell, Manufacturing Strategy Environment Uncertainty and Performance: A Path Analitic Model, Management Science, 33, 4, 1987, 509-525.

[13] B.K. Boyd and J. Fulk, Executive Scanning and Perceived Uncertainty: A Multidimentional Model. Journal of Management, 22, 1996, 1-21.

[14] I.N. Suardhika, I.N, Integrasi Sumber Daya Strategis, Orientasi Kewirausahaan, dan Dinamika Lingkungan sebagai Basis Strategi Bersaing serta Pengaruhnya terhadap Kinerja Usaha, doctoral diss., Program Pascasarjana Fakultas Ekonomi dan Bisnis, Universitas Brawijaya, Indonesia, 2011.

[15] F.J. Miliken, Three Types of Perceived Uncertainty about the Environment: State, Effect, and Response Uncertainty, Academy of Management Review, 12, 1, 1987, 133-143.

[16] Wiklund, The Sustainability of the Entreprenurial Orientation-Performance Relationship (Baylor University, 1999).

[17] Nurhajati, Analisis Faktor-Faktor yang Mempengaruhi Kinerja dan Keunggulan Bersaing Usaha Kecil yang Berorientasi Expor di Jawa Timur, doctoral diss., Program Pascasarjana Fakultas Ekonomi dan Bisnis Universitas Brawijaya, Indonesia, 2004.

[18] Pelham, Influence of Environment, Strategy, and Market Orientation on Performance in Small Manufacturing Firms, Journal of Business Research, 45,1999, 33-46.

[19] S. Rivard, L. Raymond, and D. Verreauld, Resource Based View and Competitive Strategy: an Integrated Model of Contribution of Information Technology, Journal of Strategic Information System, 14, 2005, 29-50.

[20] J.A. Parnel, L.L. Donald, and L. Michael, Strategy as a Response to Organizational Uncertainty: An Alternative Perspective on the Strategy-Performance Relationship, Management Decision, 38, 8, 2000, 520 - 530.

[21] F. Trompenaars and P. Wolliams, A New Framework For Managing Change Across Culture, Journal of Change Management, 3, 4, $2003,361-375$.

[22] C. Kirsch, C. John, and P. Warren, The Impact of Cross-Cultural Dynamics on Change Management, Cross Cultural Management: An International Journal, 19, 2, 2012, 166 - 195.

[23] A. Harzig, and G.H. Hofstede, Planned Change in Organizations: The Influence of National Cultures, Research in the Sociology and Organizations: Cross Cultural Analysis of Organizations, 1996, 297 - 340.

[24] H. Munarwan, Resep Sukses Bisnis Ala Orang Cina (Jakarta, Indonesia: Araska, 2011).

[25] M. Rahayu, Pembelajaran Organisasi sebagai Model Proses Manajemen Strategik pada Usaha Kecil Etnis Tiongwha dalam Industri Roti/Kue di Kota Malang, doctoral diss. Program Pascasarjana Fakultas Ekonomi dan Bisnis, Universitas Brawijaya, Indonesia,2005.

[26] A. Hatum and A. Pettigrew Adaptation under Environmental Turmoil: Organizational Flexibility in Family-Owned Firms, Family Business Review, 17, 2009, 237-258.

[27] A.F. Buono and K.W. Kerber, Building Organizational Change Capacity, Management Consulting Division International Conference, 2009 p. 1-28.

[28] R. Palaniswamy and J.L. Sushil, J.L, Measurement and Enablement of Information Systems for Organizational Flexibility: An Empirical Study, Journal of Services Research, 3, 2003, 81-103.

[29] M. Butler, Managing from the Inside Out: Drawing on 'Receptivity' to Explain Variation in Strategi Implementation, British Journal of Management, 14, 2003, S47-S60.

[30] C.E. Cunningham, C.A. Woodward, H.S. Shannon, J. MacIntosh, B. Lendrum, D. Rosenbloom, and J. Brown, Readiness for Organizational Change: A Longitudinal Study of Workplace, Psychological, and Behavioural Correlates, Emerald Management Reviews, 75, 4, 2002, 377-392.

[31] H. Tsoukas and R. Chia, On Organizational Becoming: Rethinking Organizational Change, Organization Science, 13, 5, 2002 , 567582. 
[32] W.F. Glueck and L.R. Jauch, Business Policy and Strategic Management (New York, USA: McGraw Hill, 1988).

[33] R.B. Carton and C.W. Hofer, Measuring Organizational Performance Metrics for Entrepreneurship and Strategic Management Research (Glesanda Houese, UK: Edward Elgar Publishing Limited, 2006).

[34] T.L. Wheelen and D.J. Hunger, Strategic Management and Business Policy: Toward Global Sustainability (New Jersey, USA: Upper Saddle River, Prentice Hall, 2011).

[35] H.G. Chong, Measuring Performance of Small and Medium Sized Entreprises: The Grounded Theory Approach, Journal of Business and Public Affairs, 2, 1, 2008.

[36] F.O. Walumba, J.J. Lawler, and B.J. Avolio, Leadership, Individual Differences, and Work-Related Attitudes: A Cross-Culture investigation, International Association of Applied Psychology, 56, 2, 2007, 212-230.

[37] Ppotoda.org., 2012, 10 Tahun Lagi Pasar Tradisional Kota Malang Terancam Mati [www] ppotoda.org, Tersedia pada: http://ppotoda.org/2012/10-tahun-lagi-pasar-tradisional-kota-malang-terancam-mati/ [Diakses pada Juni 2012].

[38] Kurniawan. 2008. Retail Modern Berdampak Negatif [www] inprogressnews.com. Tersedia pada: http://www.inprogressnews.com/index.php/ekonomi/104 [Diakses pada: Januari 2013].

[39] W. Saddewisasi, T. Ariefiantoro, dan A. Santoso, Analisis Dampak Usaha Ritel Modern terhadapa Usaha Retail Tradisional (Studi Kasus di Wilayah Kecamatan Gunungpati, Mijen, Tembalang, dan Banyumanik), Riptek, 5, 1,2005, 31-43.

[40] A. Suman, 2011, Ritel Asing vs Pasar Tradisional [www] feb.ub.ac.id/, Tersedia pada: http://www.feb.ub.ac.id/agus-suman-ritelasing-pasar-tradisional.html [Diakses pada: Desember 2012].

[41] R. Kasali, 2007, Persaingan Ritel Tradisional vs Ritel Modern [www] kompas.com., Tersedia pada: http://www.kompas.com/kompas-cetak/0703/23/ekonomi/ 3400323.htm [Diakses pada Desember 2012]

[42] J.F. Hair, W.C. Black, B.J. Babin, R.E. Anderson, Multivariate Data Analysis (New Jersey, USA: Pearson Prentice Hall, 2010)

[43] P.N. Khandwalla, The Design of Organizations (New York, USA: Harcourt Brace Jovanovich, 1977).

[44] A.A. Sanchez and G.S. Marin, Strategic Orientation, Management Characteristics, and Performance: A Study of Spanish SME's, Journal of Small Business Management, 43, 3, 2005, 287-306.

[45] U. Sekaran, Metode Penelitian untuk Bisnis (Jakarta, Indonesia: Salemba Empat, 2006).

[46] I. Ghozali, Aplikasi Analisis Multivariate dengan Program IBM SPSS 19 (Semarang, Indonesia: Badan Penerbitan Universitas Diponegoro, 2011).

[47] A. Ferdinand, Metode Penelitian Manajemen: Pedoman Penelitian untuk Penulisan Skripsi, Tesis, dan Disertasi Ilmu Manajemen (Semarang, Indonesia: Badan Penerbitan Universitas Diponegoro, 2006).

[48] D.A.S. Chew, S. Yan, and C.Y.J. Cheah, Core Capability and Competitive Strategy for Construction SMEs in China, Chinese Management Studies, 2, 3, 2008, 203-214.

[49] D.S. Halim, 8 Kunci Sukses Usaha Toko Orang Cina (Bantul, Yogyakarta: Chivita Books, 2011). 